\title{
An Extremely Uncommon Case of Parasitic Infection Presenting as Eosinophilic Ascites in a Young Patient
}

\author{
Kemal Oncu ${ }^{a}$ Yusuf Yazgan ${ }^{a}$ Mustafa Kaplana \\ Alpaslan Tanoglu ${ }^{\mathrm{a}}$ Irfan Kucuk ${ }^{\mathrm{a}}$ Ufuk Berber ${ }^{\mathrm{b}}$ \\ Levent Demirturk ${ }^{\mathrm{a}}$
}

aGastroenterology Department and ${ }^{b}$ Pathology Department, GATA Haydarpasa

Training Hospital, Istanbul, Turkey

\section{Key Words}

Eosinophilic ascites · Parasitic infection · Albendazole

\begin{abstract}
We report the case of a 24-year-old male patient admitted for recent ascites and splenomegaly of unknown origin. The patient was referred to our institution with complaints of diarrhea, epigastric pain, abdominal cramping and weight loss over the past three weeks. The acute onset presented with colicky abdominal pain and peritoneal effusion. History revealed reduced appetite and weight gain of $7 \mathrm{~kg}$ over the last one month. His past medical history and family history was negative. He had no history of alcohol abuse or viral hepatitis infection. Laboratory data revealed normal transaminases and bilirubin levels, and alkaline phosphatase and gammaglutamyltransferase were within normal range. A diagnostic laparoscopy was performed which showed free peritoneal fluid and normal abdominal viscera. Upper gastrointestinal system endoscopy performed a few days later revealed diffuse severe erythematous pangastritis and gastroduodenal gastric reflux. Duodenal biopsies showed chronic nonspecific duodenitis. Antrum and corpus biopsies showed chronic gastritis. The ascitic fluid was straw-colored and sterile with $80 \%$ eosinophils. Stool exam was negative for parasitic infection. Treatment with albendazole $400 \mathrm{mg}$ twice daily for 5 days led to the disappearance of ascites and other signs and symptoms. Three months after albendazole treatment the eosinophilic cell count was normal. The final diagnosis was consistent with parasitic infection while the clinical, sonographic and histological findings suggested an eosinophilic ascites. We emphasize the importance of excluding parasitic infection in all patients with eosinophilic ascites. We chose an alternative way (albendazole treatment) to resolve this clinical picture. With our alternative way for excluding this parasitic infection, we treated the patient and then found the cause.
\end{abstract}




\begin{tabular}{c|l|l|l}
$\begin{array}{r}\text { Case Reports in } \\
\text { Gastroenterology }\end{array}$ & $\begin{array}{l}\text { Case Rep Gastroenterol 2011;5:139-143 } \\
\text { DOI: 10.1159/000326927 }\end{array}$ & $\begin{array}{l}\text { Published online: } \\
\text { April 12, 2011 }\end{array}$ & $\begin{array}{l}\text { O 2011 S. Karger AG, Basel } \\
\text { ISSN 1662-0631 } \\
\text { www.karger.com/crg }\end{array}$ \\
\hline
\end{tabular}

\section{Introduction}

Eosinophilic ascites is a very rare clinical situation in daily practice. It may be associated with abdominal lymphomas, peritoneal dialysis, eosinophilic gastroenteritis, hypereosinophilic syndrome and also some migrant parasites [1-3]. Eosinophilic gastroenteritis is characterized by eosinophilic infiltration into one or more layers of the gastrointestinal tract [1-3]. The pathogenesis is so far poorly understood. The majority of reported cases involve the stomach and proximal small bowel. The pathogenesis and etiology of eosinophilic gastroenteritis remain unclear. Up to $40 \%$ of cases were reported to have underlying allergy. It affects adults as well as children and can involve any area of the gastrointestinal tract, although the stomach and proximal small bowel seem to be the most commonly affected [1-3]. Eosinophilic ascites is common in subserosal type of eosinophilic parasitic infections.

In adults, possible sources of parasitic infections are eating raw vegetables, raw meat or liver from potential parasitic hosts such chickens, lambs or calves [4]. We have to consider this rare disease during the differential diagnosis of unexplained gastrointestinal symptoms, especially when they are associated with peripheral eosinophilia.

\section{Case Report}

A 24-year-old man was admitted to our clinic with complaints of diarrhea, epigastric abdominal colicky pain, fatigue, nausea, vomiting and weight loss. He had previously been healthy and had no history of alcohol or drug abuse or any other medication. He was married, no travel history was reported and his social life was unremarkable. First clinical examination revealed abdominal distension and there was a suspicion of abdominal lymphomas and peritoneal tuberculosis. Our patient was afebrile, and cardiac pulse and blood pressure were within normal range. Laboratory data disclosed an increased leukocyte count $\left(22,500 / \mathrm{mm}^{3}\right.$; normal $\left.10,500 / \mathrm{mm}^{3}\right)$ with $38.8 \%$ eosinophils (absolute count 8,710 ). Transaminases and bilirubin levels were normal, and alkaline phosphatase and gammaglutamyltransferase were within normal range (table 1). Other laboratory investigations, including ferritin, Wright agglutinations for Brucella infection, Gruber widal agg., ANA, ANCA, RF and Echinococcus (IHA), were normal. Serum IgA, IgM, IgE and IgG were normal while total eosinophil cell count moderately was increased with 400 cells $/ \mathrm{mm}^{3}$ (normal value $<150$ cells $/ \mathrm{mm}^{3}$ ) Serologic studies for $\mathrm{HIV}, \mathrm{CMV}, \mathrm{HBV}$ and $\mathrm{HCV}$ were also negative. A diagnostic laparascopy was performed which did not reveal lesions of abdominal and genital organs. It confirmed the presence of a free fluid, which was sterile.

Upper gastrointestinal endoscopy showed diffuse severe erythematous pangastritis and gastroduodenal gastric reflux. Biopsies were taken from the second portion of the duodenum, gastric corpus and antrum. Duodenal biopsies showed marked chronic nonspecific duodenitis. Antral and corpus biopsies showed chronic gastritis. General examination was unremarkable, no presence of lymphadenopathy or skin lesions were noted. Lungs were clear at auscultation. The patient had a blood pressure of 130/80 $\mathrm{mm} \mathrm{Hg}$; heart sounds were normal on auscultation. The abdomen was tender with distension. Hepatomegaly and splenomegaly were noted on palpation.

Abdominal sonography revealed a moderate amount of free fluid, hepatomegaly $(181 \mathrm{~cm})$ and splenomegaly $(137 \mathrm{~cm})$. The ascitic fluid taken under sonographic guidance was clear and straw-colored. Cell count showed 1,380 cells $/ \mathrm{mm}^{3}$ with $80-90 \%$ eosinophils. Glucose, amylase and $\mathrm{LDH}$ values were normal. Direct search for parasites or larvae in the ascitic fluid and multiple peritoneal cultures were negative. Laparoscopic peritoneal punch biopsies showed eosinophilic infiltration (fig. 1). Based on these results, eosinophilic ascites was diagnosed. Finally, serologic studies for parasites disclosed negative ELISA tests for Toxocara canis and Fasciola hepatica. Unfortunately we could not study ELISA tests for giardiasis and Strongyloides stercoralis.

The differential diagnosis also included the possibility of parasitic infestation. Some intestinal parasites such as Toxocara species, S. stercoralis and Trichinella spiralis may cause visceral symptoms. 


\begin{tabular}{|c|c|c|c|}
\hline $\begin{array}{l}\text { Case Reports in } \\
\text { Gastroenterology }\end{array}$ & \begin{tabular}{|l} 
Case Rep Gastroenterol 2011;5:139-143 \\
DOI: $10.1159 / 000326927$
\end{tabular} & $\begin{array}{l}\text { Published online: } \\
\text { April 12, } 2011\end{array}$ & \begin{tabular}{|l} 
@ 2011 S. Karger AG, Basel \\
ISSN 1662-0631 \\
www.karger.com/crg
\end{tabular} \\
\hline
\end{tabular}

The stool test for ova and parasites was negative. Under this suspicion, we initiated albendazole treatment $400 \mathrm{mg}$ twice a day for 5 days. Three months later ascites was no longer apparent at sonographic evaluation and eosinophilic count decreased to $5 \%$. The patient's clinical status improved rapidly with normalization of signs and symptoms.

We conclude that in our patient, the clinical picture, laboratory findings and therapeutic results suggest the diagnosis of parasitic infection presenting as eosinophilic ascites. On follow-up he has remained asymptomatic with no further accumulation of fluid or symptoms.

\section{Discussion}

Usually human parasitic infections present with nonspecific symptoms. To the best of our knowledge, eosinophilic ascites is a rare manifestation of such infections. One of the cases described in previous case reports was treated with mebendazole, another one with albendazole and diethycarbamazine, and a third one with steroids and thiabendazole.

Visceral larva migrans may be caused by several nematodes of animals such as T. canis, Toxocara cati, T. spiralis, Ascaris suum and Anisakis. Human toxocariasis is caused by $T$. canis or rarely by $T$. cati. The adult definitive hosts are dogs and cats. The female worms may excrete up to 200,000 eggs per day. Toxocara eggs passed in the feces need several weeks of optimal environmental conditions $\left(10-35^{\circ} \mathrm{C}\right.$ high soil humidity) to develop into infective, embryonated eggs. Infection can occur by ingesting embryonated eggs or by transmission in utero from the infected mother [5]. Older dogs tend to have dormant infections. Examination of stools has no role in the evaluation of toxocariasis. The diagnosis is based on serologic findings. The enzyme-linked immunoabsorbent assay (ELISA) which employs antigen to secreted stage larvae has sufficient specificity to be the best indirect test for diagnosis of infection. The positive reaction for Toxocara antibody cannot distinguish between current and past infection. The diagnosis of active toxocariasis is based on the association of positive serological tests for Toxocara antibody and peripheral eosinophilia.

Sometimes the manifestations of human toxocariasis resemble eosinophilic ascites [6]. Experimentally induced toxocariasis in mice was associated with moderate ascites, hepatomegaly, splenomegaly, lymphadenopathy and focal lesions in liver, lung, kidney and intestine. Microscopically, focal eosinophilic ascites was found. In our patient, besides ascites and hepatomegaly-splenomegaly, the liver (transient increased aminotransferases) and abdominal lymph nodes were involved. One should look for a potential parasitic infection in all patients with symptoms of eosinophilic ascites [7].

Most cases of parasitic infections are self-limited and not life-threatening. Treatment is reserved for cases with overt manifestation such as our patient. The treatment of choice for parasitic infection is albendazole. The antihelminthic therapy is efficient in most cases; however some of them require steroid therapy. Regarding our patient, therapy with albendazole was efficient; the symptoms ceased, eosinophilic count normalized, and sonography of the abdomen showed no ascites after three months [8].

Parasitic infections are very rarely observed in our clinical practice. In Turkey no parasitic infection presenting as eosinophilic ascites has been reported so far. However, clinicians must be aware of this disease when they find high eosinophilia presenting ascites without an apparent cause. 


\begin{tabular}{l|l|l|l}
$\begin{array}{r}\text { Case Reports in } \\
\text { Gastroenterology }\end{array}$ & $\begin{array}{l}\text { Case Rep Gastroenterol 2011;5:139-143 } \\
\text { DOI: 10.1159/000326927 }\end{array}$ & $\begin{array}{l}\text { Published online: } \\
\text { April 12, 2011 }\end{array}$ & $\begin{array}{l}\text { O 2011 S. Karger AG, Basel } \\
\text { ISSN 1662-0631 } \\
\text { www.karger.com/crg }\end{array}$ \\
\hline
\end{tabular}

Table 1. Laboratory tests

\begin{tabular}{lll}
\hline Tests & Results & $\begin{array}{l}\text { Reference } \\
\text { values }\end{array}$ \\
\hline Aspartate transaminases (AST) & $24 \mathrm{IU} / 1$ & $5-40 \mathrm{IU} / 1$ \\
Total bilirubin & $0.4 \mathrm{mg} / \mathrm{dl}$ & $0.2-1.0 \mathrm{mg} / \mathrm{dl}$ \\
Echinococcus (IHA) & negative & negative \\
Peritoneal adenosine deaminase (ADA) & $1 \mathrm{IU} / 1$ & $0-20 \mathrm{IU} / 1$ \\
Alkaline phosphatase (ALP) & $60 \mathrm{IU} / 1$ & $20-120 \mathrm{IU} / 1$ \\
Wright agglutinations & negative & negative \\
Antinuclear antibody (ANA) (EIA) & $0.071($ negative) & - \\
Alanine transaminases (ALT) & $5 \mathrm{IU} / 1$ & $5-40 \mathrm{IU} / 1$ \\
Lactate dehydrogenase & $432 \mathrm{IU} / 1$ & $200-450 \mathrm{IU} / 1$ \\
Immunoglobulin E (IgE) & $118.40 \mathrm{IU} / \mathrm{ml}$ & $<120 \mathrm{IU} / \mathrm{ml}$ \\
Angiotensin-converting enzyme (ACE) & $16 \mathrm{IU} / 1$ & $8-52 \mathrm{IU} / 1$ \\
Gammaglutamyl transferase (GGT) & $30 \mathrm{IU} / 1$ & $0-50 \mathrm{IU} / 1$ \\
Brucella Rose Bengal & negative & - \\
Anti-neutrophil cytoplasmic antibodies (ANCAs) & negative & - \\
\hline
\end{tabular}

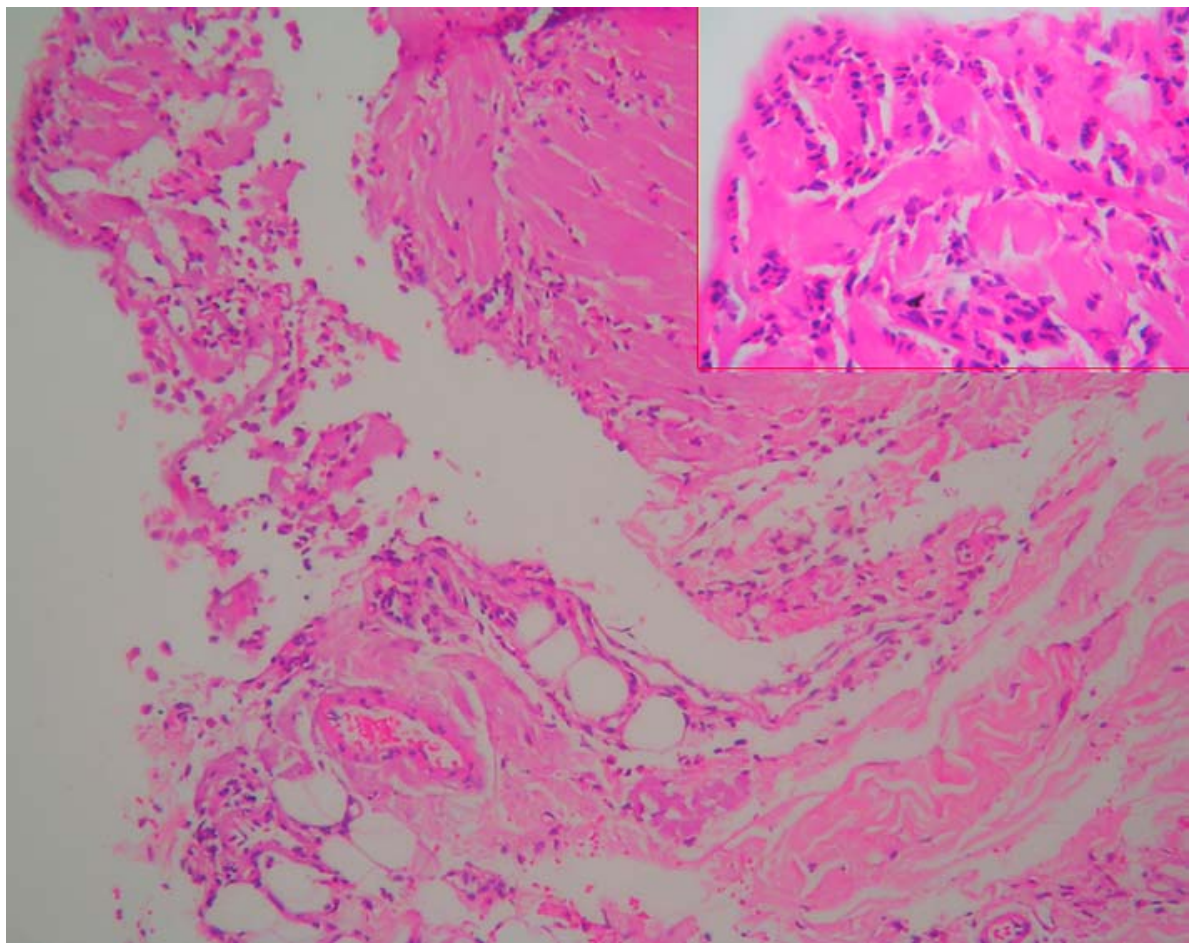

Fig. 1. Peritoneal laparoscopic punch biopsy. In this histologic view, dense eosinophilic cell infiltration with mesothelial cells is seen. Hematoxylin-eosin stain, magnification $\times 10$ and $\times 40$. 


\begin{tabular}{c|l|l|l}
$\begin{array}{r}\text { Case Reports in } \\
\text { Gastroenterology }\end{array}$ & $\begin{array}{l}\text { Case Rep Gastroenterol 2011;5:139-143 } \\
\text { DOl: 10.1159/000326927 }\end{array}$ & $\begin{array}{l}\text { Published online: } \\
\text { April 12, 2011 }\end{array}$ & $\begin{array}{l}\text { O 2011 S. Karger AG, Basel } \\
\text { ISSN 1662-0631 } \\
\text { www.karger.com/crg }\end{array}$ \\
\hline
\end{tabular}

\section{References}

1 Copeland BH, Aramide OO, Wehbe SA, Fitzgerald M, Krishnaswamy G: Eosinophilia in a patient with cyclical vomiting: a case report. Clin Mol Allergy 2004;2:7-11.

2 Chen MJ, Chu CH, Lin SC, Shih SC, Wang TE: Eosinophilic gastroenteritis: clinical experience with 15 patients. World J Gastroenterol 2003;9:2813-2816.

-3 Talley NJ, Shorter RG, Philips SF, Zinsmeister AR: Eosinophilic gastroenteritis: a clinicopathological study of patients with disease of the mucosa, muscle layer and subserosal tissues. Gut 1990;31:54-58.

4 Laufer M: Toxocariasis. e Medicine 2004:1-13.

5 Magnaval JF, Glickman LT, Dorchies P, Morassin B: Highlights of human toxocariasis. Korean J Parasitol 2001;39:1-11.

6 Cruz AT, Franklin GY, Kaplan SL: Toxocariasis causing eosinophilic ascites. Pediatr Infect Dis J 2008;27: 563-564.

7 Chira O, Badea R, Dumitrascu D, Serban A, Branda H, Hajjar N, Chiorean E, Cruciat C: Eosinophilic ascites in a patient with Toxocara canis infection. A case report. Rom J Gastroenterol 2005;14:397-400.

8 Bowman DD, Griffiths JK: Larval toxocariasis. Current treatment options. Infect Dis 2000;49:70-77. 